\title{
Challenges on Implementation of Affirmative Action in Ethiopian Secondary Schools
}

\author{
Asafa Tasgara \\ Department of Civics and Ethical Studies, Faculty of Social Science and Humanities, \\ Mettu University, Mettu, Ethiopia
}

\begin{abstract}
This study was conducted an assessment on the implementation of affirmative action in case of Ethiopian secondary schools. The general objective of this research was to assess implementation of affirmative action in case of Ethiopian secondary schools. The data were collected through primary and secondary sources. The researcher employed descriptive and explanatory types of research design. The findings from this study confirm that attitudes, perceptions practices and procedures related to affirmative action in Ethiopian secondary schools provide indicators of the challenges at implementation. In addition the researcher identified awareness-raising and sensitization plays a pivotal role in understanding the principle underlying affirmative action policies and practices. Keywords: Affirmative action; remedies, positive discrimination; implementation; nondiscriminatory laws
\end{abstract} DOI: $10.7176 / \mathrm{JAAS} / 72-02$

Publication date:May $31^{\text {st }} 2021$

\section{Induction}

Women in Ethiopia faced a variety of legal, economic, and social constraints. They are victims of harmful traditional practices and domestic violence, they were deprived of access to education, training, employment and political education, training, employment and political participation reinforced by stereo typical attitudes. Burdened with domestic labor, they are debarred opportunities from taking part in the labor force, and therefore underrepresented in public and professionalism life, often confined to clerical occupations at best, and to lawpaying semi-skilled jobs like garment manufacturing and food processing (Dereje Tegyibelue, 2008:7)

Affirmative action, policies as means of rectifying age old discriminatory practices have been controversial issues world wise such controversies have existed in countries like the USA and India in which affirmative action is believed to have a long history and in south Africa where the concept of affirmative action was introduced recently. As far as Ethiopia is concerned diverse view points exists as to the relevancy of affirmative action for women. Some vehemently argue that affirmative action is necessary as means of achieving gender equality while others contend that affirmative action should be abolished to enable women to compete at an equal footing with men. Such on-going debates are conducted in various gender forums and workshops organized in Ethiopia (Halima Mohammed, 2009: 10-11)

Despite changes in the law and policies over the past decades to help overcome the age old patriarchal practices against women, the traditional views still remain as deeply ingrained in society needless to say, this has resulted in the continuing subordinate position of women in the Ethiopia society. In light of this, the position of women in the Ethiopia society. In light of this, the position of women in Ethiopia was one of the most serious issues that has been debated among politician and scholars like, and subjected to scouting of changed over the past decades (Abay Akemachew, 2010:3).

The women have the inferior status when compared with the men on many spheres for instance the women are less participants in management of the common property they have with their housebound and they also paid less wages than men in the daily works, these are happening by disregarding the opportunity given to the women by the ruling government different laws, such as FDRE constitution and other subordinate laws. This study focuses on evaluating the legislation and results of implementation of affirmative action at the meantime, it also evaluated the attitudes and perception of beneficiaries and non-beneficiaries of the programs. This research aims at discovering the limitations hindered the women to exercise their affirmative action rights guarantee by the constitutions and other laws. In return, the research will provide the better solutions to take, those identified limitations by facilitate the methods through which reformed policy aimed at striking balance between priory harmed women and respected men will implemented in good manner in Ethiopian secondary schools.

\section{Methods and materials}

This study was conducted through descriptive and explanatory types of research design supporting by mixed research approach, i.e qualitative and quantitative in order to correctly describe, analysis and present those data. Descriptive research helped the researcher to identify the implementation of affirmative action. Besides, it will support the research to answer the reading questions that study passed and meet it general and specific objectives. 


\section{Source of data}

In this study primary and secondary data source has been used. The secondary data was obtained from reviewing available literature, journals and books reviewed.

\section{Challenges to implementation of Affirmative action.}

According to the informants view in Ethiopian secondary schools there are challenges to implementation of Affirmative action, these challenges are inability of woman's cooperation to complete the programs purpose, low lack of affirmative action implementing institutions commitment their responsibility as needed by the programs.

The other challenges that reflected by the informants are, the self-discourage of the beneficiary of the Affirmative action program the impact of the religious institutions, the customer of the society which gives less respect and capacity for women to act the things and extra incidental problems are challenges the effective implementation of Affirmative action in Ethiopian secondary schools

As stated above the challenges to implementation of Affirmative action are a sire from two separate angle, i.e from the beneficiaries of right themselves and the implementing institutions. The beneficiaries does not dedicate themselves for the least opportunity opened to them by negligence of implementing institution, due to their less cooperation, low level of Awareness towards their right and the deeply rooted idea of not claim for their equality right. On the other hand implementing institution are not discharge their responsibility as in the at home purposed strategy of the affirmative action program, due to lack of resource knowledge - etc.,(pursuant to the beneficiaries of the Affirmative action rights).

\section{Attitudinal}

It has been suggested by the managers of Ethiopian secondary schools woman's Affairs that much of the Attitudes about affirmative action seems to have resulted from the misunderstanding of the concept of Affirmative action. The attitudes towards something can a make that things properly if it is reasonable to that thing and it can also dramatically hinder such thing when it rooted on use less concepts which contrary to the needed and exact concepts which ought to have been and forgotten as a result of attitude is connected towards everything implementation of Affirmative action could never escape from this societal attitude.

Hence this section assesses the attitude and perceptions people Ethiopian secondary schools towards affirmative action and it also investigates the prevailing factors that impedes Affirmative action implementation.

\section{Perceptions}

According to the informants the underlying assumption in the debate is than and individuals understanding of what affirmative action entails will certainly in the his or her attitude. Much of the controversy about confusion and disconcertion's concerning affirmative action in the main source for the lack of understanding of main premises underlying affirmative action indeed, lack of sensitization of Affirmative action programs which often resulted from lack of conceptual clarity by policy implement do constitute the major challenges. During interviews was taken place with a number of respondents, it was alleged that many officials themselves does not have the knowledge of the principle, related to affirmative action. In this regard, it is noticeable that even those civil servants who would like to comply with the policy may lack the required awareness of what they could have to do and not do.

The least awareness of both beneficiaries of Affirmative action results, a great destruction on the at home aims of principle of implementation of Affirmative action. Since even if the beneficiary of Affirmative action claim to their own rights, the implement of the programs, due to the below standard of their awareness.

\section{Impact of religious institution}

The informant confess that the religions institutions have play the great role in the creation of negative attitudes and basing the strongly rooted concept of women inferiority one, the principle and preaching of the religions institution are obeyed and respected by the followers of the religions than the government binding rules and lows. This is because the followers of the religion institution are in fear of what they are belief to and they have absolute acceptance for the concept offered to them from their religion institution.

As a result, most of the religions followed by the society of Ethiopian secondary schools such as orthodox, Muslim, protestant and catholic religion institution uphold the superiority of men and inferiority of women. This concept has its base from the past negative attitude, which across the lairy of centurips and yet stand strongly.

Therefore, one of the challenges for effective implementation of Affirmative action in Ethiopian secondary schools school is the woman's inferiority conception fruited in the religions institutions.

\section{Customary practice}

The researcher have also informed by the informant as the some of customary practice developed in Ethiopian secondary schools has their own impact on the effective implementation of Affirmative action. The harmful 
practice, that are discriminating moments from meeting participation, prohibiting women from the management of their own house and command property they have produced with their own spouse, etc., are also in use, despite of the implementation of Affirmative action which has devised to eliminate such practices.

\section{Beneficiaries self-discourage}

One can inter from the wording of informant and as well as from the response of respondents, that the beneficiaries of affirmative action program, themselves are in the hot sleep yet. Let alone the lay beneficiaries, the literally beneficiaries even are not wake up to recovers their pasty violated rights and not fully claiming for their post affirmative action program offense against their affirmative action rights, such a kind problem can simply presumed as a great, since the group given rights are losing it by the gross negligent and carelessness. As views of informant they very sorrow and difficult be simply changed challenge for affirmative action implementation is the beneficiaries are fail to self-help.

\section{Conclusion}

This research objected to putting out the main challenged for the effective implementation of affirmative action in Ethiopian secondary schools. It analysis the problem that hinder and being the obstacle to the effective implementation in Ethiopian secondary schools. The mechanisms needed for effective implementation of affirmative action to increase women's representation in educations, employment and other spheres. The methods for the active and efficient implementation of affirmative action in Ethiopian secondary schools are enumerated in the content of the research. The research is also aimed at explaining the possible solutions in Ethiopian secondary schools for good implementation of affirmative action.

Regarding to the findings from this study confirm that attitudes, perception, practices and procedures related to affirmative action in Ethiopian secondary schools Provide indicators of the challenges at implementation. While these finding alone may not provide a complete picture of the complexities related to affirmative action implementations the data collected in this research identify specific areas that can be remedied in order to achieve the objectives set out in the constitution. Generally, this study has helps to identify the possible barriers for the effective implementation of affirmative action which could serve as a basis for further research.

\section{Reference}

* AbayAkemachew, head of center of or gender and development, ECSU, April 8, 2010.

* AmareDebebe, Assistance Dean College of social studies Addis Ababa University, November 6, 2006.

* Bacchi (1996) the politics of affirmative action, women, equality and category land, university.

* Bursten in 1994: 51-53, equal employment opportunity: labor market discrimination and public policy New York de Gryter Aldine.

* Clifford, 2008: 13, equality in Lain curries and Johan dewal (ed).

* Crosby and Cordova 1996: 13-490 word worth of wisdom: toward and understanding of affirmative action.

* DerejeTeyibelu, a human resource management department head in the civil service, commission, march 16 , 24 and April, 25, 2008.

* Dworking, Ronald M, 1985: 15-19 matter of principle (Harvard University Press, com bridge, mass 1985).

* Elizondo and Crosby 2004: 73-96 Attitudes towards affirmative action as a function of the strength of Ethnic identify among Latino college students.

* Halima Mohammed (Ambassador) women Affirms and affirmative action general directorate at MDFA, September 23, 2009.

* Holt, 2003, Strict constitutional scrutiny is not total in fact: federal courts up hold affirmative action program in public contracting.

* Kellough, 2006:3, understanding affirmative action: policies, discrimination and the search for justice.

* Krank (2002) Affirmative action, US facts on five Inc.

* Kravitz, 1995 Attitudes towards affirmative action plans.

* L.Heureux-Dube, 1997, making a difference, the pursuit of Equality and a compassionate justice 1997.

* Rosenteld, 1991: 139, women's affairs and affirmative action general directorate.

* Schuck, 2002: 56 Affirmative actions past, present and future, 20(1): 1-19.

* Sinderman PM, carmines EG 1998 reaching Beyond Race, Cambridge, MA, Harvard, university.

* Somwell, 2004: 9 affirmative action around the world empirical study.

* Toylor-carter MA. Dove spike D, Alexander R, 1995.

* Yeasin A.M Affirmative action for women in higher education and the civil service. The case of Ethiopia. 